\title{
Clonagem humana: aspectos éticos
}

\author{
Human cloning: ethical aspects
}

\author{
Daniel Romero Muñoz'
}

Muñoz DR. Clonagem humana: aspectos éticos. Saúde, Ética \& Justiça. 2004;9(1/2):5-8.

RESUMO: A clonagem da ovelha "Dolly" fez aflorarem dilemas morais, que desencadearam um temor inopinado, que acarretou, em vários países, a proibição desse tipo de pesquisa. $O$ autor expõe alguns desses dilemas e discute seus aspectos éticos à luz dos conhecimentos atuais, enfatizando que a melhor política não é proibir mas controlar. Defende que o Brasil tem mecanismos que podem ser utilizados para manter esse tipo de pesquisa sob controle, mas é preciso que continue empenhado em desenvolver o senso ético, principalmente, dos seus futuros pesquisadores.

DESCRITORES: Clonagem de organismos/tendências, Ética, Bioética.

\section{A proibição da clonagem}

Saber que o homem pode brincar de Deus e produzir um animal completo a partir do núcleo de uma célula glandular colocado dentro de um óvulo, causou um susto inesperado, em muitas pessoas, suscitando dúvidas e perguntas. A possibilidade da ciência fazer seres humanos em laboratório, despertou nosso medo atávico diante do mistério da vida e gerou pânico. O Vaticano condenou veementemente a clonagem da Dolly e pediu que qualquer experiência de duplicação de animal fosse proibida. $O$ presidente dos Estados Unidos proibiu a destinação de verbas públicas para pesquisas nessa área.
Outros países seguiram a mesma linha, proibindo pesquisas dessa natureza com medo de que fossem feitas clonagens humanas. No Brasil, a lei que regulamentou o uso das técnicas de engenharia genética já coibia não apenas a clonagem, mas estendia a proibição para qualquer pesquisa com células germinativas humanas'.

\section{Os dilemas da clonagem}

Muita gente ficou apavorada ao pensar que no futuro nosso mundo poderia ser povoado por seres

\footnotetext{
${ }^{1}$ Professor responsável pelas disciplinas de Medicina Legal da Faculdade de Medicina da Universidade de São Paulo e Bioética e Medicina Legal da Faculdade de Ciências Médicas da Santa Casa de São Paulo. Endereço para correspondência: Daniel Romero Muñoz. Rua Teodoro Sampaio, 115. CEP: 05405-000 Cerqueira César, São Paulo, SP. E-mail: drmunoz@bol.com.br
} 
humanos que seriam cópias xerográficas de uma única pessoa, sem nenhuma individualidade. Imagine a possibilidade de se fazer clonagem humana, de se clonar, por exemplo um Hittler; o nazismo poderia dominar o mundo! Afinal, poder-se-ia produzir exércitos por esse processo!

Por outro lado, um casal viu na clonagem a possibilidade de ter de volta o filho morto pela violência urbana, isto é, clonar esse filho de modo a ressuscitá-lo. Essa pretensão levou à hipótese de mortos voltarem a viver, de ressuscitarmos pessoas mortas.

Muitos se assustaram com a possibilidade de, no futuro, termos uma multidão de mortos vivos, cópias xerográficas de seres humanos, sem individualidade.

Além disso, alguns cientistas lembraram que nos Estados Unidos, o National Institute of Health aprovou em 1994 uma resolução para concessão de verbas para pesquisas com embriões humanos até o décimo quarto dia de vida, quando começa a formação da notocorda! Ocorre que não sabemos, cientificamente, quando começa a vida humana: quando um agrupamento de células torna-se pessoa? Será que é na concepção? Será que é quando surge a notocorda, o primeiro esboço do futuro sistema nervoso? ${ }^{2}$

Por outro lado, a clonagem poderá ser muito útil para a produção de tecidos ou mesmo órgãos inteiros para pacientes que hoje necessitam de transplante. Falamos da clonagem terapêutica, que poderá salvar milhões de vidas, pois sendo feita com células da própria pessoa ou de seus parentes próximos, evitaria o problema da rejeição, que continua sendo uma das principais restrições a esse tipo de tratamento. O paciente que está na fila de transplante, esperando o órgão que Ihe possibilitará continuar vivendo e a ter uma melhor qualidade de vida, aguarda ansiosamente o avanço dessas pesquisas e que elas não sejam proibidas. O mesmo pode ocorrer com os portadores de algumas doenças consideradas, atualmente, como incuráveis, mas que poderão ter grandes benefícios com o avanço das pesquisas nessa área.

O perigo de termos pesquisadores que pensam apenas na ciência, friamente, e que fazem suas experiências sem cogitarem de ética e de humanidade, assusta e provoca a proibição das pesquisas. Entretanto, é preciso lembrar que, se estes indivíduos estiverem realmente dispostos a atingirem seus objetivos e tiverem os meios para esse empreendimento, acabarão fazendo clonagem com ou sem proibição.
Como fica, então, a moral e a ética quanto a essas possibilidades e apreensões sobre clonagem humana?

\section{Ética x Moral}

Cada povo tem seus valores e faz regras, leis, proibindo que eles sejam desrespeitados. Elas delimitam o campo de ação dos membros do grupo social para que esses valores sejam preservados. Ao conjunto de normas, escritas ou não, que ditam o comportamento do grupo social de acordo com seus costumes e tradições, denominamos moral ${ }^{3}$. Transmitida de geração a geração pela educação e pela tradição, ela faz parte da consciência histórica do grupo, da consciência coletiva de Dürkheim. Os valores, que ela procura preservar, devem ser mantidos para que o grupo social continue a existir como tal. Entretanto, há o outro lado da moeda: nosso entendimento desses valores pode mudar e há o perigo da estagnação, de passarmos a agir de certo modo só porque é assim que todos fazem; ou seja, de agirmos condicionadamente, sem pensar; de sermos transformados em uma "manada de bisões" que, em disparada, acompanha cegamente o que vai à frente e se ele cair no precipício, a "manada" inteira cai atrás. Ética, por sua vez, é entendida como o ramo da filosofia que estuda a moral. Seu objetivo é procurarmos o melhor, ou seja, estudarmos os comportamentos ditados pelos costumes, os valores e as normas do grupo social, e assumirmos as nossas próprias ações. É adotarmos, conscientemente, a conduta que julgamos ser a melhor e não fazermos as coisas de determinada maneira só porque é assim que todos fazem. A Ética exige que revisemos continuamente nossos valores e os princípios de verdade em que eles se embasam. Exige também que nossa conduta seja pautada nesses princípios mais elevados ditados por nossa consciência moral ${ }^{4}$.

Os "dilemas éticos"desencadeados pela clonagem, expressam o conflito entre a nossa consciência individual e a consciência coletiva; é a luta entre dois elementos que devemos revisar e harmonizar continuamente: nossos princípios de verdade e os valores que embassam a moral social.

É com esse tipo de postura que devemos analisar as questões da ética e da moral frente à clonagem humana. 


\section{Clonagem humana: realidade ou ficção?}

A clonagem humana, atualmente, é apenas um exercício de imaginação e futurologia, principalmente no que tange à sua aplicação para fazer um ser humano completo. O que é uma realidade e, portanto, podemos e devemos discutir, são as experiências sobre clonagem humana. Desse modo, quando falamos em moral e ética na clonagem humana estamos nos referindo aos aspectos morais e éticos das pesquisas sobre essa clonagem. Outrossim, é preciso ressaltar que a clonagem é apenas uma técnica, um tipo de procedimento científico, que não é bom nem mau. O que pode ser bom ou ruim é o seu uso, a finalidade da aplicação dessa técnica. Coibir as pesquisas sobre clonagem é como proibir o cultivo de microorganismos patogênicos por medo de que sejam utilizados para uma guerra bacteriológica ou impedir as pesquisas com energia nuclear porque pode servir para a produção de armas atômicas.

Neste sentido, não concordamos que a proibição desse tipo de pesquisa seja a melhor solução. Coibi-las é voltar ao obscurantismo das proibições da idade média. A pesquisa científica produz novos conhecimentos, aprimoramentos técnicos, que poderão trazer muitos benefícios, diminuindo doenças, dando melhores condições de saúde ao ser humano, que, desse modo, poderá ter uma vivência mais plena. Ademais, proibi-las não garante que ninguém irá fazê-las. O que poderá ocorrer com a proibição é que elas sejam feitas de forma criminosa e sem nenhum controle.

Em suma, os perigos que essas pesquisas poderão acarretar não devem inviabilizá-las, mas exigem de nós uma postura de cautela, isto é, mantê-las sob controle. Em se tratando de pesquisa, por outro lado, os aspectos morais e éticos estarão centrados em quem está ou estará capacitado para utilizar essa técnica, basicamente, o pesquisador e a instituição de pesquisa.

\section{O controle da pesquisa}

O primeiro nível de controle ético das pesquisas, portanto, é a consciência do próprio pesquisador.

O ideal é que ele tenha uma consciência ética elevada e por isso o principal objetivo, em termos de ética em pesquisa, é formar a consciência ética do pesquisador. O equipamento primordial do pesquisador não é um laboratório bem aparelhado e sim uma mente bem preparada para a pesquisa. Um país para fazer pesquisa de "ponta" tem que ter pesquisadores capazes. A principal preparação para a pesquisa não é a compra do equipamento ou da alta tecnologia, mas a preparação dos seus cientistas. Preparar a mente do pesquisador não significa apenas ensinarIhe o domínio das técnicas mais avançadas, mas também, dar-lhe um cabedal filosófico e até mesmo artístico e religioso, que o possibilite ter o aparelhamento crítico necessário para, ao planejar e desenvolver uma pesquisa, não ver apenas as vantagens científicas da mesma, mas realizá-la com ética e também com arte e com humanismo. Desse modo, um pesquisador bem formado certamente fará pesquisa visando, em primeiro lugar, o bem estar do ser humano a ela submetido, e, secundariamente, ao bem que ela poderá trazer a todos os outros seres vivos.

Outro nível de controle deve ser exercido pela instituição onde essas pesquisas serão feitas. Ninguém pode fazer esse tipo de experiência nos fundos do quintal de sua casa; certamente precisará de verbas e de laboratórios bem aparelhados. Somente instituições de comprovado gabarito, que tenham essas condições, deverão ser habilitadas para realizá-las, o que torna viável o controle.

O protocolo de pesquisa, no qual o pesquisador apresenta o planejamento da pesquisa que pretende fazer, terá que passar por uma comissão de ética em pesquisa da instituição, o qual, após aproválo, deverá submetê-lo a um nível de controle superior, o governamental.

No Brasil, já existe esse tipo de controle, institucional e governamental, sobre as pesquisas em seres humanos desde outubro de 1996. A Resolução 196/96 do Ministério da Saúde criou a Comissão Nacional de Ética em Pesquisa (CONEP), ligada ao Conselho Nacional de Saúde e tornou obrigatório os Comitês de Ética em Pesquisa (CEP) nas instituições onde se faça pesquisa com seres humanos, pois se não o tiverem, seus projetos terão que passar por um CEP de outra instituição. Por essa regulamentação, todo protocolo de pesquisa em ser humano tem que ser aprovado pelo CEP da instituição responsável, o qual deverá noticiar à CONEP a realização do estudo. Outrossim, nas áreas de genética e reprodução humanas e algumas outras áreas consideradas cruciais em pesquisa, após aprovação pelo 
CEP institucional, o protocolo terá que ser enviado para Brasília para ser aprovado pela CONEP e, só depois de passar por esse processo, poderá ser iniciado o estudo 5 .

Há, também, o crivo social, pois, além de terem que ser publicadas para conhecimento de todos, os Comitês de Ética em Pesquisa, não são compostos apenas de pesquisadores, devendo ter representantes da sociedade, como por exemplo, teólogos, sociólogos, advogados, donas de casa, representantes dos pacientes a serem submetidos a pesquisas. Ademais, eles podem ter, no máximo, 50\% de uma mesma categoria profissional. São, portanto, multidisciplinares e com uma representação ampla da própria sociedade, o que faz com que cada pesquisa ao ser aprovada tenha sido submetida, indiretamente, ao crivo do grupo social.

Essa é a melhor conduta, em nosso entender, sobre como proceder com as pesquisas científicas sobre clonagem: não proibi-las, mas mantê-las sob controle.

\section{Palavras finais}

A possibilidade de termos no futuro, um mundo de mortos vivos, cópias xerográficas de seres humanos, sem individualidade, apavora muita gente. Se formos, porém, buscar uma resposta na nossa tradição hebraico-cristã, segundo a Gênese Bíblica, somos todos filhos de Adão e Eva e esta foi feita de uma costela de Adão. Assim, pode-se levantar a hipótese de sermos todos, de certa maneira, produtos de um procedimento semelhante à clonagem: viemos todos de um único indivíduo. Apesar disso, somos tão diferentes uns dos outros. Em outras palavras, pela Gênese Bíblica, existe a possibilidade de sermos o produto de uma "clonagem" que deu certo, que veio sofrendo mutações através dos tempos e por isso deu tanta diversidade 6 .

Por outro lado, na nossa tradição religiosa hebraico-cristã e também na filosófica grega, o homem não é formado só do corpo; tudo o que existe ou são coisas ou são essências e o ser humano é uma coisa (corpo) animada por uma essência (alma). Surge então a pergunta: ao fazermos a clonagem de um ser humano, clonamos apenas o seu corpo ou também a sua alma? A nossa tradição nos responde que esta última é a parte divina em nós e, certamente, não conseguiremos cloná-la. Ademais, somos diferentes não só por termos corpos diferentes, mas por termos almas diferentes.

Assim sendo, haver cópias de seres humanos, todas iguais, poderá ser apenas uma semelhança externa. É como se todos comprássemos carros da mesma marca e modelo: estaremos todos com carros exatamente iguais, mas os motoristas serão diferentes.

Muñoz DR. Human cloning: ethical aspects. Saúde, Ética \& Justiça. 2004;9(1/2):5-8.

ABSTRACTS: Moral dilemmas have greatly increased since the birth of Dolly, the clone sheep, and those led to an unreasoned and misinformed argumentations to prohibit this kind of research in many countries. In this article the author examines the reasons of those dilemmas in the light of bioethics and the update knowledge, emphasizing that the best politics is not the prohibition but the control of freedom research. Particular attention is paid to the question of the that in Brazil there is mechanism that would be used to get this kind of research under control, but effort is necessary to developing of ethical sense, mainly, of the future researchers.

KEY WORDS: Cloning, organism/trends, Ethics, Bioethics.

\section{REFERÊNCIAS}

1. Brasil. Leis, decretos, etc. Lei $n-8.974$. Dispõe sobre a biosegurança. Diário Oficial da União, Brasília, DF. 05 jan. 1995.

2. Almeida M, Muñoz DR. Início da vida: as fronteiras do conceito. Saúde Ética Justiça. 1999;4(1/ 2):1-6.

3. Ferreira ABF. Novo dicionário Aurélio da língua portu- guesa. Rio de Janeiro: Nova Fronteira; 1986. p.1158.

4. Muñoz DR. O papel da ética. Rev Bras Otorrinolaringol. 2003;69(2 supl):1-10.

5. Ministério da Saúde. Legislação brasileira. Resolução 196/96. Bioética. 1996;4(2 supl):15-25.

6. Bíblia. Português. Bíblia Sagrada: Gênesis. Trad. de A. P. Figueiredo. Rio de Janeiro: Barsa; 1965. 